\title{
Lumen
}

Selected Proceedings from the Canadian Society for Eighteenth-Century Studies

\section{John Locke, Memory, and Narratives of Origin}

\section{Patricia C. Simmons}

Volume 21, 2002

URI : https://id.erudit.org/iderudit/1012268ar

DOI : https://doi.org/10.7202/1012268ar

Aller au sommaire du numéro

Éditeur(s)

Canadian Society for Eighteenth-Century Studies / Société canadienne d'étude du dix-huitième siècle

ISSN

1209-3696 (imprimé)

1927-8284 (numérique)

Découvrir la revue

Citer cet article

Simmons, P. C. (2002). John Locke, Memory, and Narratives of Origin. Lumen,

21, 61-85. https://doi.org/10.7202/1012268ar

Copyright (C Canadian Society for Eighteenth-Century Studies / Sociéte canadienne d'étude du dix-huitième siècle, 2002
Ce document est protégé par la loi sur le droit d'auteur. L'utilisation des services d'Érudit (y compris la reproduction) est assujettie à sa politique d'utilisation que vous pouvez consulter en ligne.

https://apropos.erudit.org/fr/usagers/politique-dutilisation/ 


\section{John Locke, Memory, and Narratives of Origin}

It is perhaps a critical commonplace to identify John Locke as the founding father of an emerging modern conception of identity that is not only fluid and forged in the matrix of idiosyncratic historical circumstances, but one that also continually draws on memories of the past. ${ }^{1}$ In this we can see incipiently in Locke's epistemological reflections on the self the seeds of current debates about the constructed nature of identity and the possibility of agency, while at the same time discern how Locke's formulation of personal identity as the consciousness of self-memory underpins subsequent historical conceptualizations of the nation, the emergence of psychoanalytic discourses of the self, and recent articulations of alternate historical narratives. And yet as much as Locke endorses a model of self that resists the imposition of external meanings by legitimating subjective self-recollection as the grounds of identity, what intrigues me here is the way in which the inability to remember functions in Locke's epistemology. More specifically, what implicitly informs Locke's rigorous scrutiny of understanding in the Essay, in so far as that entails grasping one's own consciousness as the condition of thought, is coming to terms with inaccessible origins. This failure of memory to access directly one's own origin extends in Locke's political writing to a cultural inability to remember precisely the birth of the nation. Here the trope of an unremembered birth serves the rhetorical function of enabling Locke to construct a narrative of origins that supports his own view about the emergence of political society and the consequent nature of political obligation. In the following discussion I aim to bring into relief Locke's implicit preoccupation with inaccessible

1 For the various kinds of support that invisibly underpin this paper, I remain grateful to Mark W. Walma, Rebecca Gagan, Colin J. Burrow, David L. Clark, the Association of Commonwealth Universities, the Social Sciences and Humanities Research Council of Canada, the National Chapter of Canada IODE, and King's College, Cambridge. 
origins in the Essay in order then to suggest that this anxiety provides him with a way of figuring the beginnings of political society in the Two Treatises of Government.

The pervasive desire to explain the present through its relation to the past, and more specifically through its relation to the beginning of things, informs Locke's attempts to delineate what he so often calls 'new originals.' Where the Essay aspires to delineate an account of knowledge acquisition other than that afforded by the dominant theory of innatism that presupposed foundational principles inscribed on the mind by the finger of God, the Two Treatises similarly argues for an account of the origins of political society other than that offered by patriarchalism that located a foundational claim to absolute authority in Adam by right of divine donation. ${ }^{2}$ It is not, however, simply that Locke sought to supplant a divine origin with a human one, especially since all of his writings are informed by abiding theological concerns; rather, Locke took seriously the question of origins in terms of understanding the process of historical development - of how we come to know the world and how civil society has acquired its present formation. But here Locke's epistemological concerns extended implicitly to his reflections on history in so far as he acknowledged the inaccessibility of past worlds that exist beyond the reach of our capacities. Locke's recognition of memory's inability to access foundational moments, figured as birth and infancy, nonetheless facilitates the articulation of a concept of identity that is freed from the necessity of a legitimating origin and derived from the accessible domain of living memory. If we see Locke in this light, as one who writes new narratives of origin that displace its legitimating func-

2 'For if the Ideas be not innate, there was a time, when the Mind was without those Principles; and then, they will not be innate, but be derived from some other Original.' John Locke, An Essay concerning Human Understanding, (1690) ed. Peter Nidditch (Oxford: Clarendon Press, 1975) I.iv.1. 'We must seek out some other Original of Power for the Government of Politys then this of Adam.' John Locke, Two Treatises of Government, (1690) ed. Peter Laslett (Cambridge: Cambridge University Press, 1960; reprint, 1988) I.ix.83; see also I.xi.149; II.i.1. Further embedded parenthetical references to the Essay and the Two Treatises are from these editions. For the prevalence of the doctrine of innate knowledge, see John Yolton, John Locke and the Way of Ideas (Oxford: Oxford University Press, 1956) 26-71. For the ideological power of patriarchalism, see John Dunn, The Political Thought of John Locke: An Historical Account of the Argument of the 'Two Treatises of Government' (Cambridge: Cambridge University Press, 1969), and James Daly, Sir Robert Filmer and English Political Thought (Toronto: University of Toronto Press, 1979). 
tion, what emerges is a revaluation of the ostensibly ahistorical foundationalist aims of Locke's epistemology and political theory. ${ }^{3}$

\section{Memory and Identity in the Essay concerning Human Understanding}

Memory, in an intellectual Creature, is necessary in the next degree to Perception. It is of so great moment, that where it is wanting, all the rest of our Faculties are in a great measure useless: And we in our Thoughts, Reasonings, and Knowledge, could not proceed beyond present Objects, were it not for the assistance of our Memories.

John Locke, An Essay concerning Human Understanding (II.x.8)

Memory, as the proverbial storehouse of all our ideas, occupies a prominent place in Locke's theory of cognition. It is a precondition of all knowledge acquisition, including subjective knowledge of the self; as such, memory makes possible the integrity of personal identity in so far as that entails consciousness that 'can be extended backwards to any past Action or Thought' (II.xxvii.9). ${ }^{4}$ And yet, perhaps unsurprisingly in a treatise that is concerned to map out the limitations of human cognitive faculties, Locke repeatedly identifies memory as integral to knowledge and then proceeds to detail its irreparable faults. The Essay is replete with insistent reminders about memory's inability to retain ideas if not constantly renewed, almost as if the reader might forget this observation in the course of reading. Although memory is figured as a repository for ideas acquired from sensation or reflection, its unreliability consists in dissipation:

There seems to be a constant decay of all our Ideas, even of those which are struck deepest, and in Minds the most retentive; so that if they be not sometimes renewed by repeated Exercise of the Senses, or Reflection on those kind of

3 Ian Hacking pointedly articulates this assessment: 'Locke's Essay concerning Human Understanding is as nonhistorical a work as we could imagine. ... It is about the origins of ideas and the origins of knowledge.' See "Two Kinds of "New Historicism" for Philosophers,' New Literary History: A Journal of Theory and Interpretation 21, no. 2 (1990): 354 .

4 For specific discussions of memory in relation to cognition, see II.x.1-10 and IV.i-iii; personal identity and consciousness of self-memory, see II.xxvii.9-29. 
Objects, which at first occasioned them, the Print wears out, and at last there remains nothing to be seen. (II.x.5)

Locke elsewhere describes a man in whom 'decrepid old Age has blotted out the Memory of his past Knowledge, and clearly wiped out the Ideas his Mind was formerly stored with' (II.ix.14) to ask whether such a one can be considered above the condition of a cockle or an oyster. At the other extreme, Locke makes a characteristic appeal to the minds of children:

Many of those Ideas, which were produced in the Minds of Children, in the beginning of their Sensation (some of which, perhaps, as of some Pleasures and Pains, were before they were born, and others in their Infancy) if in the future Course of their Lives, they are not repeated again, are quite lost, without the least glimpse remaining of them. This may be observed in those, who by some Mischance have lost their sight, when they were very Young; in whom the Ideas of Colours, having been but slightly taken notice of, and ceasing to be repeated, do quite wear out; so that some years after, there is no more Notion, nor Memory of Colours left in their Minds, than in those of People born blind. (II.x.5)

That which punctuates the Essay is a formulation that makes the possibility of knowledge depend on memory, yet emphasizes the inescapable defects of human memory that make it a shaky foundation. While the catalogue of weaknesses afflict each individual's retentive ability to varying degrees, Locke posits more fundamental defects as constitutive of human memory. As a corollary to the fact that even the most tenacious memory cannot retain all ideas, the mind can only view a limited number of ideas at once. Locke points to the omniscience of God and to the several degrees of angels who 'probably have larger views, and some of them [may] be endowed with capacities able to retain together, and constantly set before them, as in one Picture, all their past knowledge at once' (II.x.9). Human minds, by contrast, are confined to viewing ideas only in succession, and this necessary partiality of perspective can only ever draw from a limited store of ideas that are always already fading away.

In this, Locke's depiction of human memory as a fundamentally and irrevocably flawed faculty of mind resonates with the same epistemological concerns about limitations that inform his treatment of sensory experience. That is, memory is figured as a kind of sense of the mind, the only inlet to the mind for ideas derived from experience in the past, in much the same way that the five senses of sight, smell, sound, touch and taste form the inlets for ideas derived from experience in the body. And in a treatise that is so self-conscious about recognizing the limits of our 
capacities, coming to terms with the attenuated reach of human memory tallies with Locke's pervasive argument that there are things that lie forever beyond our comprehension. ${ }^{5}$

This figuration of memory as a faculty of mind that is limited in ways similar to sensory perception bears important ramifications in terms of having access to the grounds of one's material existence. The implication that we can have had experiences but have no memory of them, no subjective access to earlier moments of existence, not only informs our daily lives wherein forgetfulness interrupts consciousness so that we lose sight of our past selves (II.xxvii.10), but more disconcertingly constitutes the very beginning of all human life. Consider, for instance, Book IV of the Essay where Locke, discussing our knowledge of the existence of God, forces the reader to consider the implications of having such a tenuous grasp of his or her own beginning:

Others would have Matter to be eternal, notwithstanding that they allow an eternal, cogitative, immaterial Being. This, tho' it take not away the Being of a GOD, yet since it denies one and the first great piece of his Workmanship, the Creation, let us consider it a little. Matter must be allowed eternal: Why? Because you cannot conceive how it can be made out of nothing; why do you not also think your self eternal? You will answer, perhaps, Because about twenty or forty Years since, you began to be. But if I ask you what that You is, which began then to be, you can scarce tell me. The Matter whereof you are made, began not then to be: for if it did, then it is not eternal: But it began to be put together in such a fashion and frame, as makes up your Body; but yet that frame of Particles, is not You, it makes not that thinking Thing You are; ... therefore when did that thinking Thing begin to be? If it did never begin to be, then have you always been a thinking Thing from Eternity; the absurdity whereof I need not confute, till I meet with one, who is so void of Understanding, as to own it. (IV.x.18)

Locke's questions bear repeating: 'But if I ask you what that You is, which began then to be, you can scarce tell me ... therefore when did that thinking Thing [You] begin to be?' By asking the reader directly to consult his or her memory for a definitive answer as to when that thinking Thing You are' began to be, Locke forcefully points up the limits of memory and the obscurity of origins. Or more precisely, by prodding the reader to distinguish between his or her material origin, the moment of birth, and the beginning of a thinking self, Locke forces the reader to 
acknowledge an existential aporia regarding subjectively apprehending the origin of consciousness. This has important ramifications for personal identity that consists in consciousness:

For it being the same consciousness that makes a Man be himself to himself, personal Identity depends on that only.... For as far as any intelligent Being can repeat the Idea of any past Action with the same consciousness it had of it at first, and with the same consciousness it has of any present Action; so far it is the same personal self. For it is by the consciousness it has of its present Thoughts and Actions, that it is self to it self now, and so will be the same self as far as the same consciousness can extend to Actions past or to come. (II.xxvii.10)

The implication here is that consciousness, and hence personal identity, is demarcated by memory; and yet clearly there is an earlier originary moment when matter was first 'put together in such a fashion and frame, as makes up your Body' (IV.x.18). Considering the importance for Locke of firsthand experience, and his insistent reminder that everything he says in the Essay derives from his own experience, how can he represent his own earliest experiences of which he has no memory?

In his chapter on personal identity, Locke states: 'Finite Spirits having had each its determinate time and place of beginning to exist, the relation to that time and place will always determine to each of them its Identity as long as it exists' (II.xxvii.2). And yet Locke's own inscrutable origin remains singularly outside of rigorous scrutiny in the Essay, beyond the direct reach of his own memory. This perhaps sheds critical light on an otherwise amusing passage in a posthumous biography written by Locke's amanuensis, Pierre Coste, wherein Locke is reputed to have often said that he had forgotten the year of his birth but believed he had written it down somewhere. ${ }^{6}$ That Coste searched Locke's papers for the date of his birth indicates perhaps no more than a literal-minded response to what seems a jocular comment; however, the reported incident is nonetheless interesting for its resonance with a thematic concern in the Essay about the limitations of human memory that render origins inaccessible. Unlike Sterne's Tristram Shandy who narrates the circum-

6 'I shall not pretend to tell you at what age he died, because I do not certainly know it. I have often heard him say, he had forgot the year of his birth; but that he believed he had set it down somewhere. It has not yet been found among his papers; but it is computed that he was about sixty six.' Pierre Coste, 'The Character of Mr. Locke,' (dated 10 December 1704) in A Collection of Several Pieces of Mr. John Locke, Never before printed, or not extant in his Works (London: J. Bettenham, 1720) xxiv (sig. b4 ${ }^{\mathrm{b}}$ ). 
stances surrounding his conception and birth, attributing his mediated self-knowledge to anecdotes and memorandums, Locke's authorial narrator takes his own consciousness as the very object under examination. ${ }^{7}$ Indeed, the extent to which his cognitive faculties alone are capable of accessing particular areas of existence not only constitutes Locke's explicit purpose in the Essay, but also finds rhetorical expression in the enactment of Locke's own memory that cannot subjectively apprehend his own earliest experiences.

Unlike the physical senses that are usually fully formed at birth, memory, as a faculty of mind, does not immediately begin to register actions and keep a record of the time and order of acquiring ideas. ${ }^{8}$ It is this delay between birth, the material origin, and the recording activity of memory that preoccupies Locke, not only because it frustrates his desire to think through the origination of his own ideas, but equally because it enables the location of a secondary foundational moment amenable to rational reconstruction. Here I differ from the reading offered by Cathy Caruth who argues that, for Locke, what is wrong with the doctrine of innate ideas 'is that it puts the origins of ideas in the wrong place, a place that is inaccessible to reason.' Accordingly, the Essay 'essentially relocates these origins from an extra-experiential realm (before and outside of reason) to a place that is completely available to rational inspection. ${ }^{9}$ Rather, I see this delay between birth and memory disturbing the possibility of examining the origination of one's own ideas because memory cannot provide such access. In this, Locke's representation of the origins of self-knowledge ultimately entails a formative and foundational stage that remains beyond the reach of memory, outside the purview of self-understanding.

This failure of memory in grasping the grounds of his own existence perhaps explains Locke's fascination with children in the Essay, in his correspondence, and more extensively in his writings on education. Throughout the Essay, the reader is often asked to think about the way a child manifests its ideas - for instance, how it distinguishes between its mother and a stranger, associates the idea of goblins with darkness, or conceives gold as the shining yellow part of a peacock's tail. Indeed,

7 Cf. Laurence Sterne, The Life and Opinions of Tristram Shandy, Gentleman, (1759-67) ed. Ian Campbell Ross (Oxford: Oxford University Press, 1983; reprint, 1987) 7, 9, 32-3.

8 Essay, I.iii.23; II.i.6.

9 Cathy Caruth, Empirical Truths and Critical Fictions: Locke, Wordsworth, Kant, Freud (Baltimore: Johns Hopkins University Press, 1991) 6-7. 
Locke repeatedly points to children as observable phenomena that exemplify his arguments about such things as the absurdity of innate ideas, the association of ideas, or the gradual acquisition of ideas through sensation. ${ }^{10}$ Besides identifying actual children as a readily available source for understanding the origins of knowledge, Locke performs several thought experiments on a notional child who, as white paper, becomes a virtual whiteboard for testing hypotheses about the acquisition of ideas or the retentive function of memory. For instance, if a child were kept in a place where he only saw black and white until he were a man, he would not have any ideas of scarlet or green; or, if a child had the use of his eyes until he could distinguish colours but then had cataracts shut the windows for forty or fifty years during which he loses the memory of the colours, if his sight is later restored, he would have no former acquaintance with the ideas of the colours; or if a man born blind, who knew a sphere and a cube by touch, had his sight restored, would he be able to distinguish the shapes by sight? ${ }^{11}$ Indeed, in his critique of the doctrine of innate ideas that comprises the first book of the Essay, and the foundational stage of his epistemology, Locke foregrounds the legibility of children in identifying them as a site where the rational adult can observe the mind in its natural state:

For Children, Ideots, Savages, and illiterate People, being of all others the least corrupted by Custom, or borrowed Opinions, Learning, and Education, having not cast their Native thoughts into new Moulds; nor by super-inducing foreign and studied Doctrines, confounded those fair Characters Nature had written there; one might reasonably imagine, that in their Minds these innate Notions should lie open fairly to every one's view, as 'tis certain the thoughts of Children do. (I.ii.27)

Locke looks to newborns as blank or white paper to observe the very lack of characters indelibly inscribed there. To observe the origin and acquisition of knowledge, Locke repeatedly instructs the reader to follow the development of children from the moment they first come into the

10 For references to children and infancy, see I.ii.5; I.ii.12; I.ii.15-17; I.ii.23-27; I.iii.20-25; I.iv.2-7; I.iv.11; I.iv.19-20; II.i.6-8; II.i.21-22; II.ix.5-7; II.x.5; II.xi.8; II.xvi.7; II.xxxiii.10; III.ii.3; III.ii.7; III.iii.7-8; III.vi.26; III.ix.9; III.ix.17; IV.vii.9; IV.vii.11; IV.vii.16; IV.xii.3; IV.xx.9.

11 II.i.6; I.iv.20; II.ix.8. See also I.iv.11 for the example of a colony of children placed on an island having no innate idea of fire. 
world. ${ }^{12}$ But while Locke's attentiveness to the early rearing of children intimates a displaced desire to access directly his own beginnings, it also enables him to locate a formative period that transpires prior to memory and can serve as a template from which to reconstruct and reclaim those foundational moments of personal history.

Locke's speculations about the foetus in the womb instance such a rational reconstruction of gestation because he has access to this period neither through memory nor through direct observation. Rather, his conjectures about the experience of the foetus are based solely on the study of newborns as part of his larger argument that infants come into the world with only faint ideas such as hunger, thirst, or warmth. ${ }^{13}$ Similarly, Locke isolates this formative period, between birth and the ambiguous time when children begin to think (I.ii.25), as a stage that can be understood through rational analysis of developing children that correlates attitudes and behaviours with experiences that took place before memory began to record the time and order of acquiring ideas. And this notion of a formative period becomes crucial for Locke's redescription of the origination of ideas, structured as a narrative of early childhood, that supplants the nativist claim to moral principles having been inscribed by the finger of God on the mind at birth. What Locke provides is a more encompassing narrative that accounts for the indisputable existence of conflicting beliefs at the same time that it explains why individuals continue to regard their tenets as innate. One reason why the theory of innate ideas wielded such explanatory power is that,

12 For specific directives, see I.iv.2; II.i.6-8; II.i.21-22; II.x.5. For Locke's reference to the child's unprejudiced understanding as white paper, see I.iii.22; II.i.2. In his unpublished essays on the law of nature, delivered as lectures at Christ Church in Oxford, Locke claims that it appears worth our labour to investigate the first beginning of this knowledge and to inquire whether the souls of the newly-born are just empty tablets.' See Essays on the Law of Nature, (c. 1663-64) trans. W. Von Leyden, in Locke: Political Essays, ed. Mark Goldie (Cambridge: Cambridge University Press, 1997) 96. Locke concludes Some Thoughts concerning Education by saying his foregoing directives were designed 'for a Gentleman's Son, who being then very little, I considered only as white Paper, or Wax, to be moulded and fashioned as one pleases.' See Some Thoughts concerning Education, (1693) ed. John W. and Jean S. Yolton (Oxford: Clarendon Press, 1989) 265. Although Locke used the famous phrase, tabula rasa, in Draft B of the Essay, the metaphor of 'white paper' occurs in the Essay in all its published editions, signifying the mind in its original state which is itself figured as the mind of a child at birth. See John Locke: Drafts for the 'Essay Concerning Human Understanding,' and Other Philosophical Writings, ed. Peter Nidditch and G.A.J. Rogers (Oxford: Clarendon Press, 1990) 128. Cf. Locke, Essay, II.i.2.

13 I.iv.2; II.i.21; II.ix.5; II.ix.7; III.iii.7. 
given the constitutive weakness of human memory, there is no remembrance of the beginning:

When Men, so instructed, are grown up, and reflect on their own Minds, they cannot find any thing more ancient there, than those Opinions, which were taught them, before their Memory began to keep a Register of their Actions, or date the time, when any new thing appeared to them; and therefore make no scruple to conclude, That those Propositions, of whose knowledge they can find in themselves no original, were certainly the impress of God and Nature upon their Minds; and not taught them by any one else. (I.iii.23)

In this Locke seeks to undermine the cogency of the seventeenth-century predisposition to regard precepts inculcated during infancy as sacred, and therefore divinely prescriptive, because one cannot remember learning them. ${ }^{14}$ Indeed, what needs to be accounted for is the origination of ideas that seem innate because immemorial, ideas that men conclude to be 'as ancient in their Minds as their very Memories' (IV.xx.9). But if we think of Locke's preoccupation with the minds of children as the displacement of his thwarted desire to recover his own origin through memory, we can see immediately that his delineation of an interim period between origins, the origin of the body and the origin of the conscious self, in no way rectifies the subjective inaccessibility of our beginnings. Since childhood is not preserved through memory, at least not that foundational portion prior to the full functioning of memory, Locke's model of self-understanding acknowledges its inherent probabilism. But this probabilistic model nonetheless offers a reassuring normative narrative of childhood from which the thinking self can infer its own beginning that is not accessible through memory. Here narrative supplements memory in the rational reconstruction of personal identity.

14 In Locke's unpublished essays on the law of nature, which prefigure his critique of innate ideas in the Essay, we can observe this embryonic thesis about how the opinions of parents and teachers insinuated themselves into our unguarded and tender minds, leading us to conclude 'that they are inscribed in our hearts by God and by nature, since we observe no other origin of them.' See Locke, Essays on the Law of Nature, (c. 1663-64) 98-99. 


\section{Cultural Memory in the Two Treatises of Government}

Thus, though looking back as far as Records give us any account of Peopling the World, and the History of Nations, we commonly find the Government to be in one hand, yet it destroys not that, which I affirm, (viz.) That the beginning of Politick Society depends upon the consent of the Individuals, to joyn into and make one Society; who, when they are thus incorporated, might set up what form of Government they thought fit.

John Locke, Two Treatises of Government (II.viii.106)

It is possible to think about this normative narrative of childhood, concerned as it is with identity, memory, and origins, informing Locke's explanation of the historical development of political society in his Two Treatises of Government. However, in order to contextualize what Locke is doing in the Two Treatises, it might be helpful here to bear in mind two related points about the conceptual priority ascribed to origins in the seventeenth century. Firstly, it was assumed that the political arrangements in England's remote past had a direct bearing on the present. ${ }^{15}$ In this regard, John Pocock has perhaps best delineated the prescriptive force of the ancient constitution that existed since time out of mind, beyond memory, yet was accepted as legitimating present political arrangements. ${ }^{16}$ What Pocock terms the 'common-law habit of mind' shaping the interpretation of English history as continuous and unchanging enabled a particular structure of thought that enshrined the notion of immemoriality. Pocock elucidates the paradox: to define law as custom in opposition to written law would seem to imply 'that the law is in constant change and adaptation, altered to meet each new experience in the life of the people'; curiously enough, the very opposite inference was drawn:

15 For a discussion of the historical form of seventeenth-century political arguments, such that remote English history was assumed to be relevant to deciding between rival positions, see Quentin Skinner, 'History and Ideology in the English Revolution,' Historical Journal 8, no. 2 (1965) 151-78.

16 J.G.A. Pocock, The Ancient Constitution and the Feudal Law: A Study of English Historical Thought in the Seventeenth Century (Cambridge: Cambridge University Press, 1957; reprint, 1987) 30-69. 
The common lawyers, holding that law was custom, came to believe that the common law, and with it the constitution, had always been exactly what they were now, that they were immemorial: not merely that they were very old, or that they were the work of remote and mythical legislators, but that they were immemorial in the precise legal sense of dating from time beyond memory beyond, in this case, the earliest historical record that could be found. This is the doctrine or myth of the ancient constitution. ${ }^{17}$

Of particular interest here is the conceptual priority given to the immemorial. The unwritten common law defined as immemorial custom presupposed the existence of a time beyond memory, time out of mind, such that the unquestionable authority of the ancient constitution inhered largely in its having no discernible origin. Secondly, since the heated debates about sovereignty that marked the seventeenth century were motivated by the desire to circumscribe royal prerogative, the way to codify the proper sphere of royal power was assumed to depend upon establishing the source of political authority. Did the authority of the king originate in the will of the people such that he was not only entrusted with the responsibility to govern, but himself bound by the laws of the land? Or was the king divinely appointed such that he could not be subject to the law and remained unaccountable to anyone but God? During the first years of Charles I's reign, Sir Robert Filmer, in his political treatise entitled Patriarcha, argued that monarchical power inhered in the natural right of fathers to rule absolutely, and that Adam, the first monarch, enjoyed this right to absolute rule which passed through patrilineal succession to the present king of England. Patriarcha remained unpublished until 1680 when the Tories claimed Filmer as a spokesman to refute the notion that humankind had ever enjoyed a state of natural liberty in which to choose a form of government. ${ }^{18}$ And it is Filmer's patriarchalism which Locke attacks in the First Treatise before setting out his own theory about the contractual origins of political society in the Second.

17 Pocock, Ancient Constitution, 36.

18 Despite its first publication in 1680, the composition of Filmer's Patriarcha has been dated variously between 1628 and 1648. See Johann P. Sommerville, 'The Date of Filmer's Patriarcha,' in Robert Filmer, Patriarcha and Other Writings, ed. Johann P. Sommerville (Cambridge: Cambridge University Press, 1991) xxxii-xxxiv. Sommerville has tentatively concluded that the Chicago manuscript was written before 1631, and that the Cambridge manuscript dates from 1635-1642. 
It is not, however, simply the case that Locke ascribes to political society a human origin instead of a divine one. Indeed, as with his efforts in the Essay to disabuse people of the inclination to think sacred that which has no remembered beginning, what Locke fashions in the Two Treatises is a more persuasive narrative of origins that explains why some might mistakenly think that the absolute rule of one man had always existed, and therefore was divinely authorized. While this more encompassing explanation takes the shape of an historical narrative, and indeed draws on recorded historical events as part of its evidential structure, it is possible to construe Locke's aims in the Two Treatises as having less to do with accuracy of historical representation than with the articulation of an alternate way of conceptualizing the origination of political power that changes the terms of the debate. I concede John Dunn's point that the critical problem in Locke's mind was 'the problem of the legitimacy of contemporary societies, rather than the prehistoric origin of such a legitimate order.' ${ }^{19}$ And yet, given the predominant habit of mind that sought legitimacy in origins, as evidenced by the prevailing mode of political reasoning that appealed to the prescriptive force of the ancient constitution, the more fundamental conceptual shift Locke needed to facilitate involved changing the legitimating function that was ascribed unthinkingly to origins. This offers a new approach to an old question: namely, why is it that Locke, unlike all other political writers of the age, makes no appeal to the prescriptive force of the ancient constitution $?^{20}$ The range of answers typically identify Locke as an ahistorical writer, one who, unwilling to adduce history as the foundation of his political theory, shifted the argument to a sphere in which the whole appeal to history seemed

Dunn, Political Thought of John Locke, 69.

20 Both John Pocock and Quentin Skinner have flagged Locke's divergence from the prevailing way of thinking about political obligation. Skinner suggests that Locke making no appeal to the prescriptive force of the ancient English constitution 'could only have been seen by his contemporaries as a remarkable lacuna.' See Pocock, Ancient Constitution, 46, 187, 235-38; Quentin Skinner, The Foundations of Modern Political Thought, vol. 1, (Cambridge: Cambridge University Press, 1978; reprint, 1998) xiv. Because Locke 'was rejecting and ignoring one of the most widely accepted and prestigious forms of political reasoning available to him,' Skinner claims that we ought to consider 'what Locke may have been doing at this point in his argument ... whether he may not have had the intention to convey to his original readers that he saw the claims of prescription as unworthy of his attention, and thus that he was, so to speak, stating his attitude to the theory in the form of his silence.' 
irrelevant. ${ }^{21}$ My contention is that, as a socially pragmatic thinker, Locke was concerned to address the needs of Restoration England as a society paralyzed by a crisis in its self-conception. Rather than view Locke as trying to develop a non-historical theory of politics, if we think about Locke working to change a whole structure of thought that located authority within an inaccessible origin as a way out of an otherwise irreconcilable debate, we can see Locke as one responsive to contemporary historical issues. In this regard, Locke's attempt to change the way people think about the evidential status attributed to remote ages manifests his epistemological attitude towards history; that is, he recognizes the inaccessibility of primeval worlds and the consequent inadequacy of appeals to the ancient constitution. Given the political deadlock resulting from diverse positions arguing from immemorial precedent, the myth of the ancient constitution, with its prescriptive force and indefinite content, was as dangerously malleable a concept as the nativist doctrine that moral precepts are imprinted on the mind at birth. It was the very inaccessibility of that origin, as an unwritten and foundational moment, that needed to be accounted for; and it is here that Locke's epistemological reflections on memory and self-knowledge in the Essay, and his delineation of a normative narrative of childhood that enables rational reconstruction of unremembered infancies, underpin his ostensibly historical narrative of the origins of political society.

One way to distinguish between the modes of reasoning deployed by Filmer and Locke involves their respective use of historical records as evidence. Like the common-law habit of mind that adduced historical records as the instantiation of the antecedently existing constitution, Filmer cites passages from other authors and from scriptures that exemplify his claim that monarchical rule has always been absolute by virtue of fatherly authority. In this, Filmer's attempt to naturalize absolutism by claiming that it has never been otherwise was seductive in its logic of continuity originating in sacred history, at the very moment of creation. But if we think of recorded history as embodied cultural memory, Filmer's strategy of marshalling citations that evince the patrilineal succession of absolute rule recalls Locke's insistent

21 Richard Ashcraft, 'Locke's State of Nature: Historical Fact or Moral Fiction?' American Political Science Review 62 (1968) 898-915; Pocock, Ancient Constitution, 46, 187-88, 235-38; like Ashcraft, Walter M. Simon claims Locke's political theory remains essentially unhistorical since his use of history is illustrative. See 'John Locke: Philosophy and Political Theory,' American Political Science Review 45 (1951) 386-99. 
admonition in the Essay that the ideas most resistant to questioning are those that are experienced as natural and regarded as sacred because of nothing more than long familiarity in the mind and unremembered beginnings (I.iii.21-27). By contrast, Locke uses the structure of thought underpinning appeals to the ancient constitution, namely the assumed existence of a time prior to the earliest historical record, but turns it to a new end within the framework of a normative narrative of childhood that encompasses the limitations of memory. As a rational reconstruction of a formative period that remains inaccessible to cultural memory, demarcated by historical records, Locke's account of origins articulates a viable alternative to naturalized absolutism by fashioning a new cultural identity.

Unlike Filmer's appeal to familiar concepts, Locke's account of origins is predicated on conceptualizing a primeval world that is other than that political society which it founds. Locke says,

To understand Political Power right, and derive it from its Original, we must consider what State all Men are naturally in, and that is, a State of perfect Freedom to order their Actions, and dispose of their Possessions, and Persons as they think fit, within the bounds of the Law of Nature, without asking leave, or depending upon the Will of any other Man. (II.ii.4)

Locke posits his famous state of nature as the originary condition of humankind wherein free and independent men agreed that it would be prudent to set up a form of government, thus creating civil society. ${ }^{22}$ What is particularly interesting, however, is the way in which Locke defends the validity of his suggestion that such a time existed despite the fact that history gives no such account:

The inconveniencies of that condition, and the love, and want of Society no sooner brought any number of them together, but they presently united and incorporated, if they designed to continue together. And if we may not suppose

22 For an alternate discussion of memory and narrative in the Two Treatises whereby Locke writes a story that restores to people 'the memory of the first of those many contracts that constitute the fabric of society,' see Joshua Foa Dienstag, Dancing in Chains: Narrative and Memory in Political Theory (Stanford: Stanford University Press, 1997) 25-74. I think, however, that Dienstag's reading of Locke's recommendations for educating children unfairly represents Locke as one who encourages the gratuitous repression of the body, and misses completely the rationale of self-governance. 
Men ever to have been in the State of Nature, because we hear not much of them in such a State, we may as well suppose the Armies of Salmanasser, or Xerxes were never Children, because we hear little of them, till they were Men, and imbodied in Armies. (II.viii.101)

It is here that we can see clearly how Locke figures the nation as a person. Yet unlike other political writings, such as Hobbes's Leviathan where the metaphor entails the constitution of the political body, Locke anthropomorphizes the historical development of political society in such a way that ascribes births and infancies to commonwealths. ${ }^{23}$

This proves a compelling explanation for the lack of records testifying to Locke's imaginatively reconstructed state of nature:

Government is every where antecedent to Records, and Letters seldome come in amongst a People, till a long continuation of Civil Society has, by other more necessary Arts provided for their Safety, Ease, and Plenty. And then they begin to look after the History of their Founders, and search into their original, when they have out-lived the memory of it. For 'tis with Common-wealths as with particular Persons, they are commonly ignorant of their own Births and Infancies: And if they know any thing of their Original, they are beholding, for it, to the accidental Records, that others have kept of it. (II.viii.101)

Here Locke's epistemological concern with the inaccessibility of origins finds full expression as a cultural inability to remember precisely the birth of the nation. And if we think about public records as documenting cultural memory, we can see how Locke's account of origins points up the epistemological limit of historical records. When we apply this to the cultural memory of national history, public records mark the limit of memory, beyond which lies a terrain directly accessible to neither memory nor observation. But where this existential aporia troubles the Essay's attempt to think back through memory to a preformed self, to grasp the antecedently existing grounds of incipient consciousness, the resolution

23 Cf. Hobbes's use of personification whereby men 'conferre all their power and strength upon one Man, or upon one Assembly of men, that may reduce all their Wills, by plurality of voices, unto one Will: which is as much as to say, to appoint one Man, or Assembly of men, to beare their Person. ... This is more than Consent, or Concord; it is a reall Unitie of them all, in one and the same Person. ... This done, the Multitude so united in one Person, is called a COMMON-WEALTH, in latine CIVITAS. This is the Generation of that great LEVIATHAN.' Thomas Hobbes, Leviathan, (1651) ed. Richard Tuck, rev. ed. (Cambridge: Cambridge University Press, 1996; reprint, 1997) 120. 
of Locke's displaced desire through the observation of children becomes subsumed as an explanatory principle in a larger narrative about cultural origins.

Here Locke confronts directly the epistemological limitations of memory as embodied in historical records in order to tell a tale about beginnings. Locke says, 'I will not deny, that if we look back as far as History will direct us, towards the Original of Common-wealths, we shall generally find them under the Government and Administration of one Man' (II.viii.105). Recall that in the Essay Locke isolated a formative period, existing after birth and before memory began its recording function, to account not only for the troubling inaccessibility of one's own origin, but also for how ideas inculcated during infancy acquired sacred status because the grown man could not remember having ever thought differently. Similarly, to combat a naturalized conception of absolute rule, Locke posits the existence of a formative time before cultural memory began to register the dates and order of its actions, embodied in historical records, which nonetheless founded the beginning of political society. Here Locke emerges as a storyteller who offers a narrative that explains why the first men would choose to put themselves under the care of one man:

First then, in the beginning of things, the Father's Government of the Childhood of those sprung from him, having accustomed them to the Rule of one Man, and taught them that where it was exercised with Care and Skill, with Affection and Love to those under it, it was sufficient to procure and preserve to Men all the Political Happiness they sought for, in Society. It was no wonder, that they should pitch upon, and naturally run into that Form of Government, which from their Infancy they had been all accustomed to; and which, by experience they had found both easie and safe. (II.viii.107)

Again, the recurring image is of infancy which not only denotes the early formative years that are so important in Locke's thoughts on educating children, but also connotes a time of trusting innocence, of weakness and dependence.

By describing the time when men first assembled as a 'vertuous' and 'Golden Age' (II.viii.110), Locke figures the temporal origins of political society as a kind of prelapsarian period existing prior to the acquisition of knowledge through the experience of history:

Monarchy being simple, and most obvious to Men, whom neither experience had instructed in Forms of Government, nor the Ambition or Insolence of Empire had taught to beware of the Encroachments of Prerogative, or the Inconveniencies of Absolute Power, which Monarchy, in Succession, was apt to lay claim to, 
and bring upon them, it was not at all strange, that they should not much trouble themselves to think of Methods of restraining any Exorbitances of those, to whom they had given the Authority over them, and of ballancing the Power of Government, by placing several parts of it in different hands. (II.viii.107)

And yet, this primeval innocence incapable of conceiving betrayal is itself located between beginnings. On the one hand, Locke figures primitive peoples as children whose innocence consists in guileless simplicity, in being as yet unacquainted with evil and the manifold abuses of history. ${ }^{24}$ But on the other, Locke presents this state of weakness and dependence, figured by the imperfect state of childhood, as a consequence of the Fall that inaugurates human history. Here Locke foregrounds the fact that Adam was never a child in the biblical story of creation:

Adam was created a perfect Man, his Body and Mind in full possession of their Strength and Reason, and so was capable from the first Instant of his being to provide for his own Support and Preservation, and govern his Actions according to the Dictates of the Law of Reason. (II.vi.56)

By contrast, Adam's offspring 'having another way of entrance into the World, different from him, by a natural Birth' were 'all born Infants, weak and helpless, without Knowledge or Understanding' (II.vi.56). By thus locating the state of nature somewhere between the Fall and the beginning of human history, Locke tells a story about the historical development of civil society that is compelling both in deploying childhood as an explanatory concept and in accounting for the theological significance of man's first disobedience, a point that Filmer's narrative of divine donation completely elides. ${ }^{25}$ Once banished from Eden, our

24 Locke elsewhere refers to the 'unforeseeing Innocence of the first Ages' that could not then anticipate 'Successors of another Stamp' who would not preserve people's lives, liberty, and property (II.vii.94).

25 In the First Treatise, Locke provides a withering critique through close reading and rational analysis of Filmer's arguments for the scriptural justification of monarchical power invested in Adam by divine donation. Part of Locke's refutation consists in attending to scriptures as narrative to redress Filmer's misreadings. For example, in response to Filmer's claim that the subjection of Eve to Adam constituted an original grant of government, Locke says, 'The Words are the Curse of God upon the Woman, for having been the first and forwardest in the Disobedience, and if we will consider the occasion of what God says here to our first Parents, that he was Denouncing Judgment, and declaring his Wrath against them both, for their Disobedience, we 
first parents stepped into human history, into an imperfect world whose infancy is figured through their progeny: 'Adam and Eve, and after them all Parents were, by the Law of Nature, under an obligation to preserve, nourish, and educate the Children, they had begotten, not as their own Workmanship, but the Workmanship of their own Maker, the Almighty, to whom they were to be accountable for them' (II.vi.56). ${ }^{26}$ This becomes important for replacing Filmer's conception of political power originating in a divine donation of private property to the king with the poignant image of a father entrusted with the care of his innocent and dependent children:

Certain it is that no body was ever intrusted with it [the Rule] but for the publick Good and Safety, and to those Ends in the Infancies of Commonwealths those who had it, commonly used it: And unless they had done so, young Societies could not have subsisted: without such nursing Fathers tender and carefull of the publick weale, all Governments would have sunk under the Weakness and Infirmities of their Infancy; and the Prince and the People had soon perished together. (II.viii.110)

Locke certainly wanted to portray this time as necessary and formative in the development of civil society. And the fact that, in the third edition that bears Locke's handwritten revisions, 'without this care of the Governours' was crossed out and changed to read 'without such nursing Fathers tender and carefull of the publick weale' suggests that he wants us to conceptualize the beginnings of political society as a kind of infancy. ${ }^{27}$

cannot suppose that this was the time, wherein God was granting Adam Prerogatives and Priviledges, investing him with Dignity and Authority, Elevating him to Dominion and Monarchy: ...' it would be hard to imagine, that God, in the same Breath, should make him Universal Monarch over all Mankind, and a day labourer for his Life' (I.v.44).

26 For further references to children as weak, ignorant, and unable to provide for themselves, as well as the parents' responsibility to protect, nourish and educate them until they can take care of themselves, see I.ix.88-90; II.vi.60; II.vi.63-69; II.vii.78-80; II.vii.83; II.xv.170; II.xv.173; II.xviii.209. Even in the case of conquest, Locke claims that children retain a natural right to their father's property for their preservation (II.xvi.182-3). In contrast to civil society, Locke details, both in the Essay (I.iii.9) and in the Two Treatises (I.vi.57), ways in which children are treated cruelly in foreign and barbarous countries.

27 [John Locke], Two Treatises (London: Awnsham and John Churchill, 1698), sig. R6 ${ }^{\mathrm{a}}$. For his 1960 critical edition of Two Treatises, Peter Laslett used as his copy text this 
We might remember here the concept of a double origin, comprising the moment of birth and the somewhat less discernible beginnings of a thinking self, that informs Locke's treatment of personal identity in the Essay. A similar structure of thought explains the location of a secondary foundational moment in the history of political societies. Locke explicitly refers to the 'Infancy of Governments' when 'Commonwealths differed little from Families in number of People' and the 'Governours, being as the Fathers of them' watched over them for their own good (II.xiv.162). Just as Locke claims that there is certainly a time when children begin to think (Essay, I.ii.25), there is also a time when nations begin governments (Two Treatises, II.viii.110), when a nation, as a thinking thing with a subjective cultural consciousness manifested in historical records, began to be.

This conceptual affinity between the individual and the nation in terms of the formative influence of remote ages, figured as infancy and early rearing, itself had a prolonged gestation in Locke's mind. As early as 1676 Locke pondered the 'very constitution of the mind' of 'our tender age':

Who is there almost that hath not opinions planted in him by education time out of mind; which by that means come to be as the municipal laws of the country, which must not be questioned, but are here looked on with reverence as the standards of right and wrong, truth and falsehood; when perhaps these so sacred opinions were but the oracles of the nursery, or the traditional grave talk of those who pretend to inform our childhood, who receive them from hand to hand without ever examining them $?^{28}$

But if we think about Locke trying to forge a coherent political identity for England in the late seventeenth century, a new self-conception constituted by cultural consciousness extended backwards to past actions and thoughts, the latent implication in his focus on the birth and infancy of the commonwealth is that political society has now reached the age of reason. Indeed, Locke rewrote Filmer's patriarchal authoritarianism

Coste copy, which resides in the library of Christ College, Cambridge. Although Laslett reads this change as amongst Locke's concessions to patriarchalism, I contend that an equally plausible explanation reads this change as evidence of Locke rewriting patriarchal discourse for the purpose of persuading readers to accept an account of the contractual origins of political society, the very opposite of patriarchal absolutism. 
in such a way that endowed parents with the consummate responsibility to form the child's mind until the child can reason independently:

The Power, then, that Parents have over their Children, arises from that Duty which is incumbent on them, to take care of their Off-spring, during the imperfect state of Childhood. To inform the Mind, and govern the Actions of their yet ignorant Nonage, till Reason shall take its place, and ease them of that Trouble, is what the Children want, and the Parents are bound to (II.vi.58). ${ }^{29}$

While the growing child is subject to the parents' absolute rule during the prolonged period of dependence, Locke clearly insists that the parents are obligated to make decisions in the best interests of the child to produce a moral character capable of self-governance. ${ }^{30}$ Regarding parental jurisdiction Locke says, "The Bonds of this Subjection are like the Swadling Cloths they are wrapt up in, and supported by, in the weakness of their Infancy. Age and Reason as they grow up, loosen them till at length they drop quite off, and leave a Man at his own free Disposal' (II.vi.55). This normative narrative of childhood thus anticipates the child's maturation, the point at which reason takes the place of the father's rule in governing one's actions. ${ }^{31}$ After this critical point of maturation, it would be unreasonable for the father to expect the same unquestioning obedience to his commands if, as Locke says, 'out of a conceit of Authority he should have the indiscretion to treat him still as

29 In the Essay, Locke says that the well-being of his children causes delight in a father (II.xx.7). For Locke's discussion of lions and wolves obeying God and Nature in caring for their young until they can shift for themselves, see Two Treatises, I.vi.56.

30 Although Locke vehemently opposed the doctrine of innate ideas that presupposed the divine inscription on the mind of practical principles of morality, he does recognize the uniqueness of each child's mind in terms of its innate dispositions. The task of the parent, and the tutor, then becomes figuring out ways to work with the child's natural temperament to form right habits of body and mind that encourage rationality, independence, and self-governance. This period of childhood when the child is thus subjected to the absolute will of its parents, while certainly formative of the child's moral character, is not intended to produce docile subjects through an educational narrative of self-denial that makes repression of the body a sign of virtue. Rather, the absolute authority which parents have over their offspring, far from granting the parents any kind of sovereign impunity, entails the consummate responsibility to nurture self-governance in the child while curbing the inclinations towards covetousness, dominion, cruelty, or self-indulgence. See Locke, Some Thoughts concerning Education, (1693) 114, 163-4, 180-2, and passim.

31 See II.vi.55-61; II.vi.63; II.vi.66; II.vi.69; II.vi.74; II.viii.118. 
a Boy' (II.vi.68). Implicated in Locke's figuration of the beginnings of civil society as an unremembered birth and infancy is the moment at which the mature commonwealth, grown too old for conquest, can break free from the absolute rule of the father to embark on the next stage of self-governance. This moment had arrived in late seventeenth-century England and its clarion call ends the Two Treatises: 'The People have a Right to act as Supreme, and continue the Legislative in themselves, or erect a new Form, or under the old form place it in new hands, as they think good' (II.xix.243). By bringing his epistemological concerns and his fascination with children's cognitive development to bear on his political thought, Locke articulated a plausible account of origins otherwise inaccessible to cultural memory that simultaneously defused the prescriptive force customarily ascribed to origins while legitimating a cultural self-conception that was free to manifest the principles deemed reasonable in its modes of social and political organization.

John Locke was certainly not alone in his desire to return to origins. Indeed, the late seventeenth century, in its religious, philosophical, and political debates, was characterized by a pervasive concern to define the present through its relation to the beginning of things. Locke does stand apart, though, in so far as his epistemological concerns extended implicitly to his reflections on history and origins. Opposed to conceptualizations of history that either emphasized the continuity of the past with the present or dissociated the present from the distant past as completely other, Locke recognized the inaccessibility of primeval worlds, both personal and political. And this is perhaps nowhere more resonant than in his figuration of human memory as a limited facultyof mind. But what intrigues me about Locke's insistent search to find what he calls 'new originals' is his recognition that in order to make sense of one's own existence there is still a need for some sense of one's beginning. It is here that narrative supplements memory by providing a context within which to account for memory's inability to access foundational moments. But perhaps more significantly, Locke fosters a notion of personal and cultural identity that draws on experience within living memory as opposed to one that must ground itself in a legitimating origin that always exists in time out of mind, beyond the reach of memory. And it is here that we can question the appropriateness of ascribing foundationalist aims to Locke in his epistemology and political theory.

Unlike the traditional view of Locke as one aspiring to establish the ahistorical foundations of knowledge or political society, I suggest that Locke provides new narratives of origin that enable a model of self, knowledge, and society that is historical, contingent, and provisional. This model is thoroughly generational because it not only uses the normative narrative of childhood to anthropomorphize the common- 
wealth in a developmental account of national history, but also facilitates an understanding of constitutional change resulting incrementally from the decisions of successive generations. It is almost as if Locke, recognizing the foundational role of contingent beginnings, infuses his conception of self-governance with specifically pragmatic aims. Locke posits self-governance, whereby the determination of appropriate courses of action takes into consideration probable consequences, as an individual and a societal goal integral to the viability of a community whose ethical self-conception ascribes reason a guiding role. Locke thus rewrites the present as an origin, a contingent origin no doubt, but one that holds the promise of posterity. Consider his Some Thoughts concerning Education where he suggests that, in order to habituate children to the use of reason, parents ought to be particularly attentive to shaping their child's mind before memory begins its recording function. ${ }^{32}$ Here Locke's fascination with that formative period prior to memory informs his specific directives for rearing children. What began as an anxiety about the subjective inaccessibility of one's own origin through memory in the Essay and served as an explanatory concept for the unremembered birth of the nation in the Two Treatises becomes a compelling account of cognitive development that calls for conscientious parenting. ${ }^{33}$

Locke's epistemological pragmatism dissociates the present from its inaccessible origins and implicitly accepts that we are born in medias res, already in history with no direct access to our beginnings. However, recognition of the inaccessibility and contingency of our own beginnings in no way justifies the abdication of responsibility for future generations. The commonwealth is thus constituted by a generational trust that decisions made in the present take cognizance of the fundamentally binding responsibility to secure the capacity for self-governance of future generations. We might find in this model a connection between

32 'A Compliance, and Suppleness of their Wills, being by a steady Hand introduced by Parents, before Children have Memories to retain the Beginnings of it, will seem natural to them, and work afterwards in them, as if it were so; preventing all Occasions of Strugling, or Repining. The only Care is, That it be begun early, and inflexibly kept to, till Awe and Respect be grown familiar.' 'If therefore a strict Hand be kept over Children from the Beginning, they will in that Age be tractable, and quietly submit to it, as never having known any other.' Locke, Some Thoughts concerning Education, (1693) 111, 110, and passim.

33 The importance for Locke of child-rearing as a possible organizing principle of society is further suggested by his strict directives about marriage and the benefits that should accrue to procreation in his unpublished Atlantis, (1676-9) in Locke: Political Essays, ed. Mark Goldie, 252-59. 
Locke and current conceptions of identity - that is, in so far as our attempt to understand the historically contingent grounds of present forms of existence involve the simultaneous dissolution of legitimating foundations and the confident assertion of the viability of a liberal community continually refashioning its self-conception through rational consensus.

In my reading of Locke as one concerned to address inaccessible and prescriptive origins, with the intent to delegitimize the sacred status of the origin as foundational in order to articulate a self-fashioning model of personal and cultural identity, Locke emerges as one enacting the kind of pragmatic role Richard Rorty has proposed following his critique of the foundationalist, metaphysical aspirations of philosophy:

Their job is to weave together old beliefs and new beliefs, so that these beliefs can cooperate rather than interfere with one another. Like the engineer or the lawyer, the philosopher is useful in solving particular problems that arise in particular situations - situations in which the language of the past is in conflict with the needs of the future. ${ }^{34}$

Locke's attempt to find a way out of the late seventeenth-century situation of religious and political deadlock hinged on recognizing that the disputes about morality and political authority were forever irreconcilable as long as the terms in which the debates were conducted presupposed the legitimating function of an origin. Nonetheless, Locke's epistemological concern with the inaccessibility of origins found persuasive expression as a narrative of origins; the normative narrative of childhood, figuring formative and foundational moments beyond the reach of memory, not only provided an explanatory context for unremembered beginnings, but also implicitly argued against the structure of thought that located authority in an inscrutable source. Locke's dissolution of legitimating foundations was nonetheless accompanied by his recognition of the historical contingency of all belief systems and the ways in which the present functions as an origin, and bears a conscious

34 Richard Rorty, 'Philosophy and the Future,' in Rorty and Pragmatism: The Philosopher Responds to His Critics, ed. Herman J. Saatkamp Jr. (Nashville: Vanderbilt University Press, 1995), 199. For Rorty's critique of the foundationalist and metaphysical aspirations of philosophy, where he includes Locke in the pantheon of foundationalist philosophers, see Philosophy and the Mirror of Nature (Princeton: Princeton University Press, 1979) and Contingency, Irony, and Solidarity (Cambridge: Cambridge University Press, 1989). 
responsibility, for subsequent generations. Considered in this way, Locke perhaps functions as a kind of cultural midwife who bears witness to the birth of antifoundationalism, a position that has only recently come into its own, and connects us to the late seventeenth century, a time that exists beyond the reach of our own living memory.

\section{PATRICIA C. SIMMONS}

University of Cambridge 